機械構造用炭素鋼の表面脫炭と疲労強さとの

\author{
関係についての研究* \\ （第 2 報＼cjkstart表面脱炭鋼の内部応力の分布について）
}

\author{
上田太郎** 上田祐 男**
}

\title{
On the Relation between the Surface Decarburization and the Fatigue Properties of Plain Carbon Steel for Machine Construction
}

\author{
(2nd Report: On the Distribution of Internal Stress in the Cross Section \\ of the Decarburized Steel Bar)
}

\author{
by \\ Taro UEDA and Sachio UEDA \\ (Ōsaka University)
}

The distribution of internal stress in the cross section of the decarburized carbon steel bars, which were normalized, quenched and tempered, or shot-peened, were measured.

In this measurement of the internal stress, the dissolution method by acid solution was used in order to remove the outer layers of specimen without any effect of workhardening. The results obtained were as follows:

(1) In the outer portion of both the normalized and the heat-treated specimens, containing the decarburized zone, the internal stress acts as tension. This tensile internal stress gets maximum at the surface layer and sharply decreases towards the center of the specimen, till it vanishes at a certain point, which lies at a depth of around $0.5 \sim 1.0 \mathrm{~mm}$ from the surface, and afterwards changes its sign; this compressive internal stress increases towards the center.

(2) As the depth decarburized increases, each of these maximum tensile internal stress decreases. The maximum value of this tensile stress is about $52 \mathrm{~kg} / \mathrm{mm}^{2}$ in the specimen, when the depth of decarburized layer is $0.15 \mathrm{~mm}$, and it reduces almost by half when the depth is $0.5 \mathrm{~mm}$. The compressive maximum internal stresses in their center zones are about $3 \sim 6 \mathrm{~kg} /$ $\mathrm{mm}^{2}$.

(3) The distribution of internal stress in the quenched and tempered steel bar after decarburizing is similer to that of the normalized one. The surface maximum tensile stress is $35 \mathrm{~kg} /$ $\mathrm{mm}^{2}$ in the specimen having a depth decarburized of $0.15 \mathrm{~mm}$, and $15 \mathrm{~kg} / \mathrm{mm}^{2}$ when the depth is $0.5 \mathrm{~mm}$. Thus the maximum tensile stress decreases as the depth of decarburized layer increases.

(4) The value of maximum tensile internal stress in the normalized steel bar at each depth decarburized is greater than those of the quenched and tempered bar.

(5) The distribution of internal stress in the shot-peened specimen after decarburization is opposite to that of the above mentioned normalized, or heat treated steel bar.

The value of maximum compressive internal stress at the surface layer increases as the depth decarburized increases. That is $32 \mathrm{~kg} / \mathrm{mm}^{2}$ in the specimen with a depth decarburized of $0.05 \mathrm{~mm}$ and is $60 \mathrm{~kg} / \mathrm{mm}^{2}$ in the $0.5 \mathrm{~mm}$ depth specimen.

(Received Oct. 6, 1959)

\section{1. 緒}

\section{言}

機械部品として多く使用されている鉄鋼材料は，そ の製造過程において熱間圧延，鍛造あるいは熱処理な

* 原穓受付 昭和 34 年 10 月 6 日, 当協会第 5 期総会譵演会にて講演 (昭31.5)

** 正員 大阪大学工学部
どのため空気中で高温に加熱されて表面に脱炭層の形 成される場合が多い.これら表面脱炭した鋼の機珹的 性質は脱炭によっていちじるしく变化し，ことに疲労 強度に及ばす影響のいちじるしいことは第 1 報で述べ たとおりである。

鋼の表面が脱炭して内部層との間に炭素含有量に相

昭和 34 年 12 月 
違が生じ，金属組織が不均一になれば内部応力の発生 することは考えられる。また，このような脱炭鋼の表 面にショットピーニングを施して，表面層に塑性変形 と加工硬化を与えるときは，それらの内部応力の分布 は変化することも考えられる。

そこで，これら表面脱炭鋼の内部応力の分布状沉， およびその大きさを知ることは前報告の疲労試験結果 を考察するうえにも，また，表面脱炭鋼の疲労強度に 及汭す種々の影響を研究するうえにも必要なことと考 えられるので, 本研究において脱炭後焼準，および焼 入れ，焼戻し処理あるいはまた，表面脱炭したものに ショットピーニングを施したものについて，その横断 面における縦軸方向の内部応力の分布状態を測定する ことにした。

\section{2. 実験材料および試験片}

実験に用いた鋼材は炭素含有量 $0.61 \% \mathrm{C}$ の機械構造 用炭素鋼で，内部応力測定用の試験片は直径 $19 \mathrm{~mm}$ の圧延棒鋼より Fig. 1 に示す直径 $12 \mathrm{~mm}$, 長さ 140 $\mathrm{mm}$ の丸棒に旋盤仕上したもので，その化学成分，お よび脱炭方法は第 1 報の疲労試験に用いた試片と同一 である，その方法によって試験片表面に深さ $0 \cdot 15$, $0 \cdot 3$, および $0.5 \mathrm{~mm}$ の脱炭層を造り，そののち $920^{\circ} \mathrm{C}$

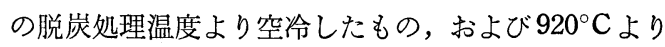
直ちに油中焼入れし， $580^{\circ} \mathrm{C}$ で 1 時間焼戻しをしたも のについて内部応力を測定した。また，ショットピー ニングによる内部応力の变化を研究するため脱炭後空 冷したものに Table 1 の条件によってショットピー ニングを施した.

\section{3. 測 定 方 法}

内部応力の測定方法としては，古くから G. Sachs の引抜鋼棒について縦軸方向の穿孔により，あるいは E. Heyn，および O. Bauer の引抜鋼棒の表面からご く少しずつ旋盤で削り取ることなどにより，引抜鋼棒 中の内部応力の平衡を乱してそのときに生ずる变形量 を測定し，これから鋼棒の横断面に作用する内部応力 の大きさを算出する方法が採用されている，本研究に おいては表面の脱炭層はわずかであるから，この部分 を数回にわけて旋盤で削り取ることは困難であり，ま たかりに削られたとしても，切削による新しい内部応 力の発生があるので, これを防ぐため, 著者の研究に

Table 1 Condition for shot-peening

\begin{tabular}{c|c}
\hline Type of machine & Centrifugal force type \\
\hline Shot-size (mm) & 0.7 cut wire shot \\
\hline Shot-velocity (mm/sec) & 65 \\
\hline Rotating speed of specimen \\
\begin{tabular}{c} 
(rpm) \\
\hline
\end{tabular}
\end{tabular}

よる酸で表面を溶去して，内部応力を測定する方法を 採用した。この方法によれば，旋盤で削るさいに生ず る内部応力の発生を防ぎ，かつ，直径が細くなるまで 溶去できるので中心近くまでの内部応力が求められる。 内部応力測定用試験片の両端にきわめて細い十字線 を引いた白金板を Fig. 1 に示すようにはりつけこ の十字線の交点を長さを測るときの標点とした．その 標点距離以外の両端を, 全部ビニール塗料で被覆して 溶去を防いだ。この試験片を $10 \%$ 硝酸溶液中に一定 時間垂直につるし，かつこれをゆるく回転させるとき は，標点距離の部分のみが外部よりなんらの応力を受 けることなく, 静かに表面より溶け去って細くなる。 試験片の表面が溶去されると同時に, 溶去前の試験片 に存在していた内部応力の平衡が破れ，新たな平衡状 態に達しようとして変形する。この長さの变化量を測 長コンパレーターにより $1 / 1000 \mathrm{~mm}$ まで測定し, 直 径の変化をマイクロメーターを用いて $1 / 100 \mathrm{~mm}$ まで, 長さ $10 \mathrm{~mm}$ ごとに直角方向に测定し，その平均值を 取って，そのときの試験片の直径とした。これらの測 定值からつぎに示す計算式を用いて各溶去層に作用す る縦軸方向の平均内部応力を求めた.

いま，第 $n$ 回の溶去後における環状層に働く平均内 部応力を $\sigma_{n}$ とすれば，

$$
\begin{aligned}
\sigma_{n}= & \left(l_{n}-l_{o}\right)\left\{{r_{o}}^{2}\left(E^{\prime}-E\right)+r_{n}^{2} E\right\} \\
- & \left(l_{n-1}-l_{o}\right)\left\{r_{o}{ }^{2}\left(E^{\prime}-E\right)+r^{2}{ }_{n-1} E\right\} \\
& / l_{o}\left(r^{2}{ }_{n-1}-r_{n}{ }^{2}\right)
\end{aligned}
$$

で与えられる。

式中の $E=$ 脱炭層のヤング率

$E^{\prime}=$ 無脱炭部のヤング率

$r_{o}=$ 試験片の最初の半径

$r_{o}{ }^{\prime}=$ 中心から脱炭層までの半径

$r_{n}=$ 第 $n$ 回目の溶去後の半径

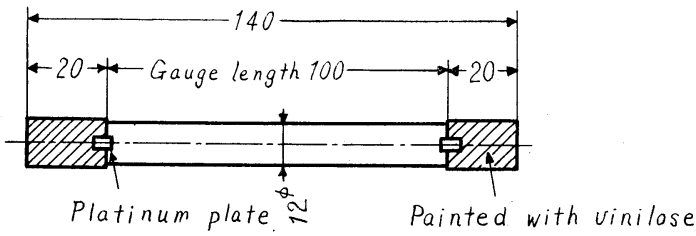

Fig. 1 Specimen for internal stress

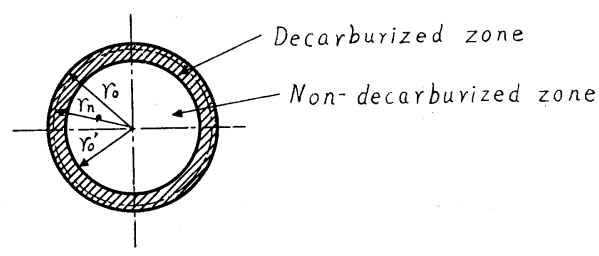

Fig. $2 r_{0}=$ Initial radius of the specimen $r_{0}^{\prime}=$ Radius of the non-decarburized zone $r_{n}=$ Radius after the $n$-th dissolution 
$l_{0}=$ はじめの試験片の標点距離

$l_{n}=$ 第 $n$ 回目の溶去後の標点距離

溶去が進えで無脱炭部との境にきて $r_{n}=r_{o}{ }^{\prime}$ になり， さらに溶去が進めば無脱炭部のみとなって，第 $n+m$ 番目の層における平均内部応力を $\sigma_{n+m} \cdot$ とすれば,

$$
\sigma_{n+m}=\frac{\left(l_{n+m}-l_{0}\right) r_{n+m}^{2} E^{\prime}-\left(l_{n+m-1}-l_{0}\right) r_{n+m-1}^{2} E^{\prime}}{l_{0}\left(r^{2}{ }_{n+m-1}-r^{2} n+m\right)}
$$

最後に残った中心部の平均応力を $\sigma_{c}$ をすれば

$$
\sigma_{c}=E^{\prime} \frac{l_{0}-l_{n+m}}{l_{0}}
$$

これらの（1)，(2)，(3) 式における $r_{n}, l_{n}$ ，および $r_{n+m}, l_{n+m}$ の各值は溶去ごとに測定されるから，そ の層に存在した平均内部応力 $\sigma_{n}$ や $\sigma_{n+m}$ を求めるこ とができる.この場合内部応力の值が正の符号をもつ ときは引張応力，負のときは圧縮応力である.

\section{4. 実 験 結 果}

試験片の表面を $10 \%$ 硝酸溶液中で溶去させた後, 直径ならびに長さの变化を測定して，それより横断面 の各層に作用する内部応力を (1)，(2)，(3) 式より

Table 2 Modulus of elasticity for pure iron and $0.61 \% \mathrm{C}$ steel

\begin{tabular}{c|c|c}
\hline \multirow{2}{*}{ Heat treatment } & \multicolumn{2}{|c|}{$\begin{array}{c}\text { Modulus of Elasticity } \\
\left(\mathrm{kg} / \mathrm{mm}^{2}\right)\end{array}$} \\
\cline { 2 - 3 } & $\begin{array}{c}\text { Decarburized } \\
\text { zone }: E\end{array}$ & $\begin{array}{c}\text { Non- } \\
\text { decarburized } \\
\text { zone : } E^{\prime}\end{array}$ \\
\hline Normalized structure & 21500 & 21050 \\
\hline $\begin{array}{c}\text { Quenched \& tempered } \\
\text { structure }\end{array}$ & 21450 & 20980 \\
\hline
\end{tabular}

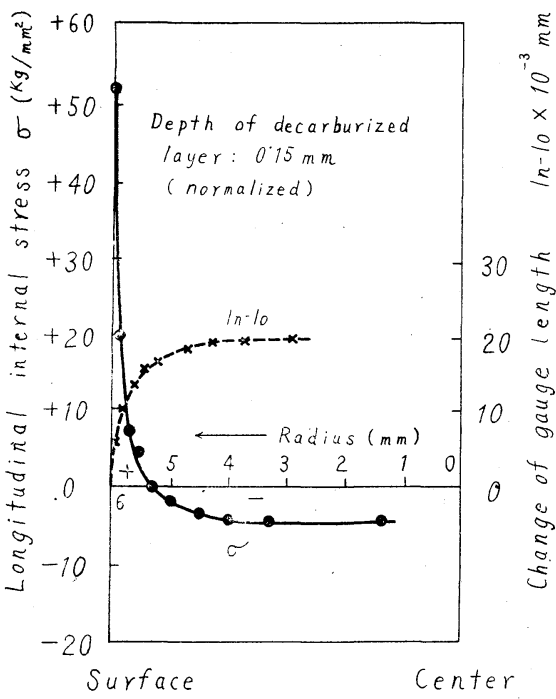

Fig. 3 The distribution of longitudinal internal stress in the cross section of decarburized carbon steel bar and the change of length caused by dissolution
算出するさい必要となる鉄，および硬鋼のヤング率の 值については，これまで多く測定されているがまちま ちであるので，著者の一人が測定した值を採用するこ ととし，その值は Table 2 に示している.

\section{（I）焼準組織の脱炭鋼棒の内部応力}

深さ $0.15,0.3$, および $0.5 \mathrm{~mm}$ の脱炭層をもつ 3 種類の直径 $12 \mathrm{~mm}$ の試片についての測定結果，およ びこれより算出した各層における内部応力の分布を図 示したものが Fig. 3〜Fig. 5 である.

Fig. 3 は深さ $0.15 \mathrm{~mm}$ の脱炭層をもつ試験片につ いての結果で, 試験片を表面から溶去してゆくと内部 応力の平衡が破れて, 新平衡状態に達するために長さ は伸び，内部応力の分布は実線で示すように外層部に は引張内部応力, 中心部には圧縮内部応力が存在し,

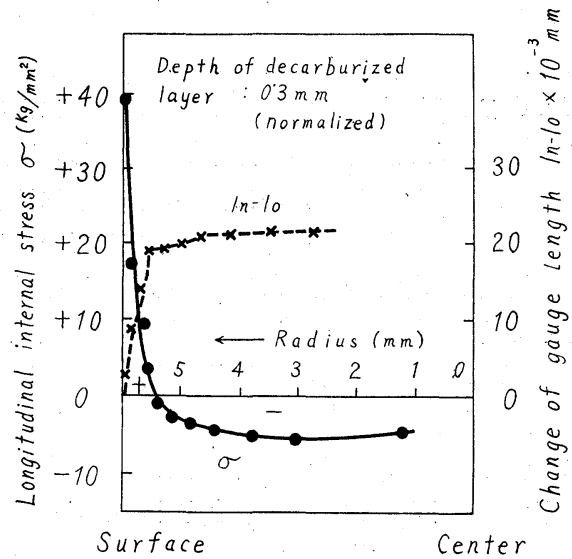

Fig. 4 The distribution of longitudinal internal stress in the cross section of decarburized carbon steel bar and the change of length caused by dissolution

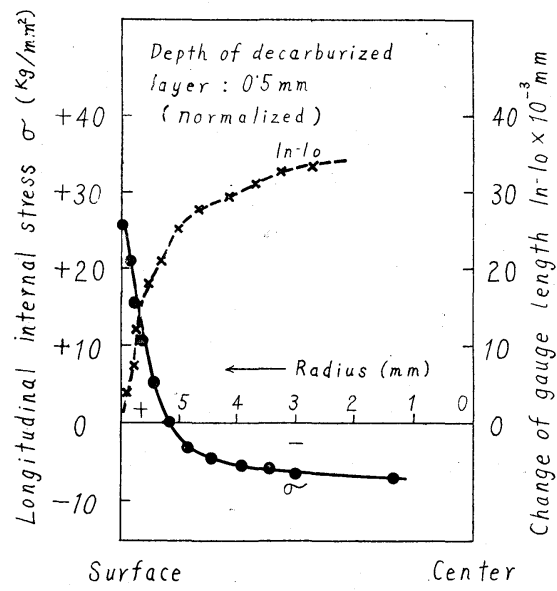

Fig. 5 The distribution of longitudinal internal stress in the cross section of decarburized carbon steel bar and the change of length caused by dissolution 
表面層における引張内部応力の最大値は約 $52 \mathrm{~kg} / \mathrm{mm}^{2}$ に達し, 中心部の圧縮内部応力の最大值は $5 \mathrm{~kg} / \mathrm{mm}^{2}$ にすぎない。

脱炭層が $0.3 \mathrm{~mm}$ ，あるいは $0.5 \mathrm{~mm}$ と深くなって も Fig. 4 や Fig. 5 に示すように内部応力の分布状態 は脱炭層 $0 \cdot 15 \mathrm{~mm}$ の場合と同様である.しかし, そ の大ささは脱炭深さが増すほど小さくなり, 脱炭深さ $0.3 \mathrm{~m} / \mathrm{m}$ の棒の最大引張内部応力は約 $40 \mathrm{~kg} / \mathrm{mm}^{2}$ で あり, $0.5 \mathrm{~mm}$ 深さのものでは約 $27 \mathrm{~kg} / \mathrm{mm}^{2}$ となっ て, 脱炭深さ $0.15 \mathrm{~mm}$ の約 $1 / 2$ に減少する.また, 引镸内部応力から压縮内部応力移り变わる点は脱炭 深さが増すとともに中心部へ移動している。

（II）焼入れ，焼戻し調梊処理した脱炭鋼棒の内部 応力

脱炭処理した試験片を油中焼入れ後焼戻しの調質処 理したものについて求めた值を示すと Fig. 6〜Fig. 8 である。

Fig. 6 は, 脱炭深さ $0.15 \mathrm{~mm}$ 試片の溶去による長 さの変化, および内部応力の分布状態を示し, 溶去す るとともに標点距離はしだいに伸び，表面層には引張 内部応力, 内部には圧縮内部応力が存在していること は狫準組織の試片と同様であるが，その值はそうとう 小さくて最大引張内部応力は $34 \mathrm{~kg} / \mathrm{mm}^{2}$ となり, 0.3 $\mathrm{mm}, 0.5 \mathrm{~mm}$ と深くなっても Fig. 7, Fig. 8 に示す ように同じような分布状態である，異なる点は，焼準 鋼に比べて表面層に働く最大内部応力の值は小さく, 脱炭梁さが深くなるに従い一層小さくなって $0.3 \mathrm{~mm}$ で, $22 \mathrm{~kg} / \mathrm{mm}^{2}, 0.5 \mathrm{~mm}$ で $15 \mathrm{~kg} / \mathrm{mm}^{2}$ である.

(III) ショットピーニングを施した脱炭鋼棒の内部 応力

深さ $0.05,0.15,0.3,0.4$ および $0.5 \mathrm{~mm}$ の脱炭

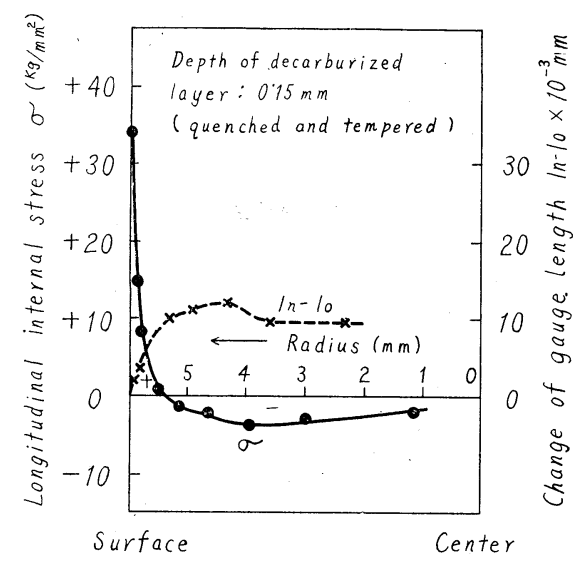

Fig. 6 The distribution of longitudinal internal stress in the cross section of decarburized carbon steel bar and the change of length caused by dissolution
深さを有する丸棒試験片に Table 1 に示す条件でシ ョットピーニングを施し，その横断面における内部応 力の分布状態を測定した結果を Fig. 9〜 Fig. 13 に示 している。

Fig. 9 は $0.05 \mathrm{~mm}$ のごく浅い脱炭層をもつものに ショットピーニングを施した場合の内部応力の分布曲 線を示したもので. 表面には圧縮内部応力, 中心部に は引張内部応力が存在しており, ショットピーニング を施さない上記の二つの場合と正反対の分布状態を示 している。また，これらの表面層の最大圧縮内部応力 は，脱炭深さが $0.05 \mathrm{~mm}$ のとき $32 \mathrm{~kg} / \mathrm{mm}^{2}$, これよ り增すに従い大きくなって，0.5 mm のものでは 60 $\mathrm{kg} / \mathrm{mm}^{2}$ に達していて, この変化状沉もまたショット ピーニングを施さない場合と正反対である。

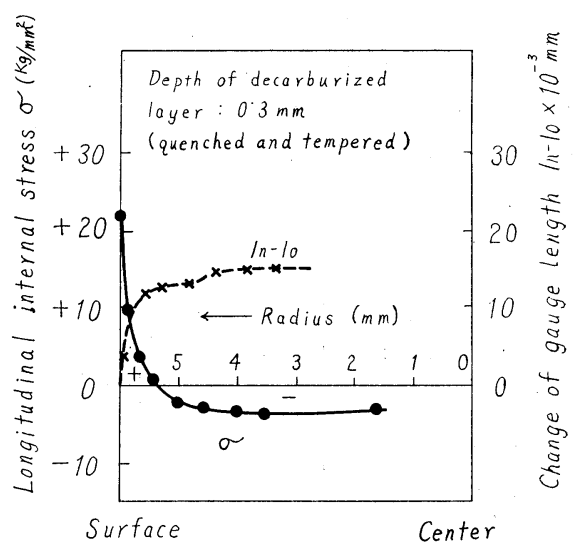

Fig. 7 The distribution of longitudinal internal stress in the cross section of decarburized carbon steel bar and the change of length caused by dissolution

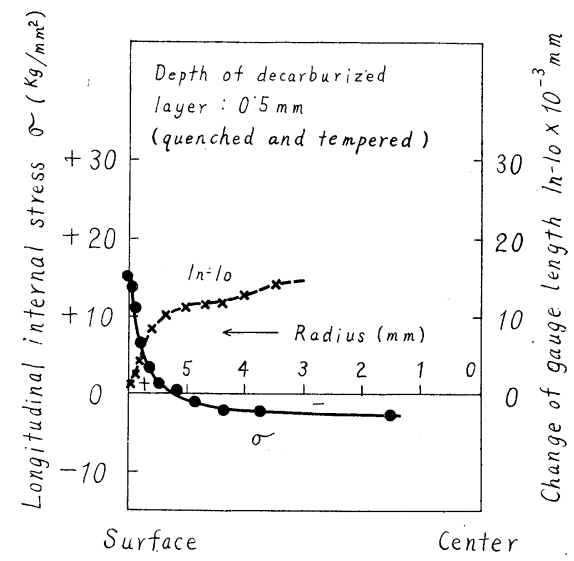

Fig. 8 The distribution of longitudinal internal stress in the cross section of decarburized carbon steel bar and the change of length caused by dissolution 


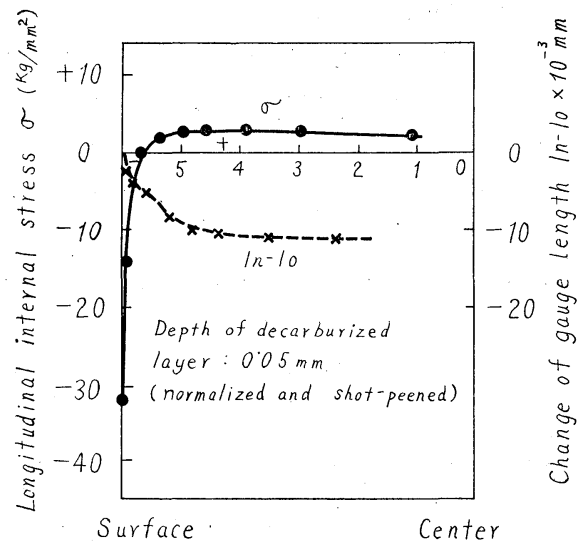

Fig. 9 The distribution of longitudinal internal stress in the cross section of decarburized carbon steel bar and the change of length caused by dissolution

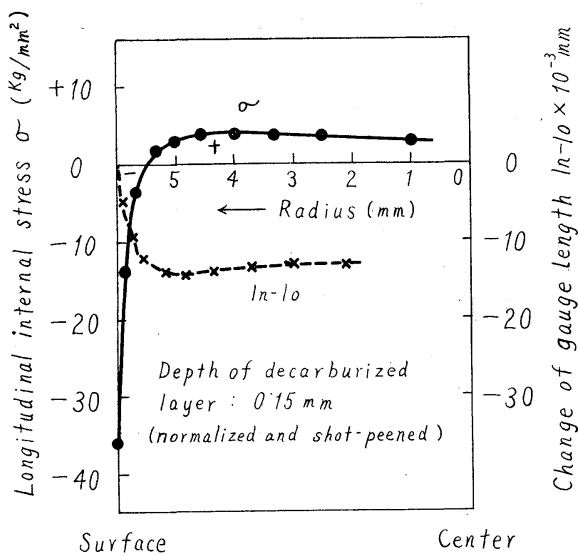

Fig. 10 The distribution of longitudinal internal stress in the cross section of decarburized carbon steel bar and the change of length caused by dissolution

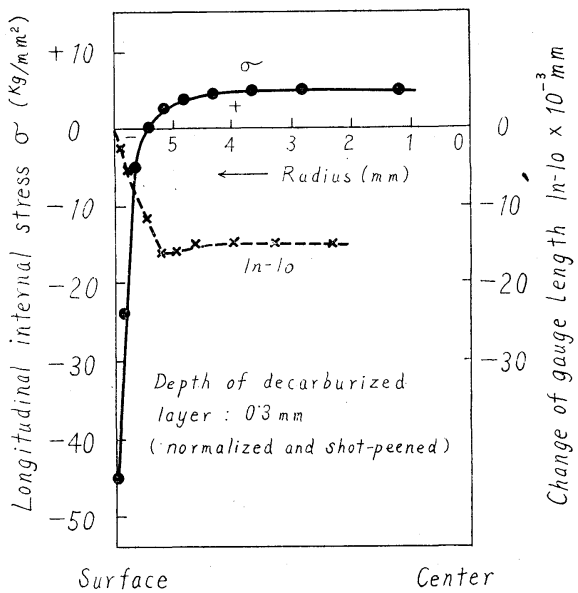

Fig. 11 The distribution of longitudinal internal stress in the cross section of decarburized carbon steel bar and the change of length caused by dissolution

\section{5. 実験結果の考察}

\section{（I）焼準組織の場合}

焼準組織をしたいずれの脱炭深さの試験片において も，横断面に存在する内部応力の分布状態はよく似て おり, 表面層に引張内部応力, 内部には圧縮の内部応 力が存在して平衡状態にある.

炭素鋼棒の表面で脱炭反応がおこれば，表面部には フェライトの多い層が形成され, 内部の炭素は外部へ 拡散して炭素量を平均しようとする。したがって, 表 面の脱炭反応速度と内部より外部への炭素の拡散速度

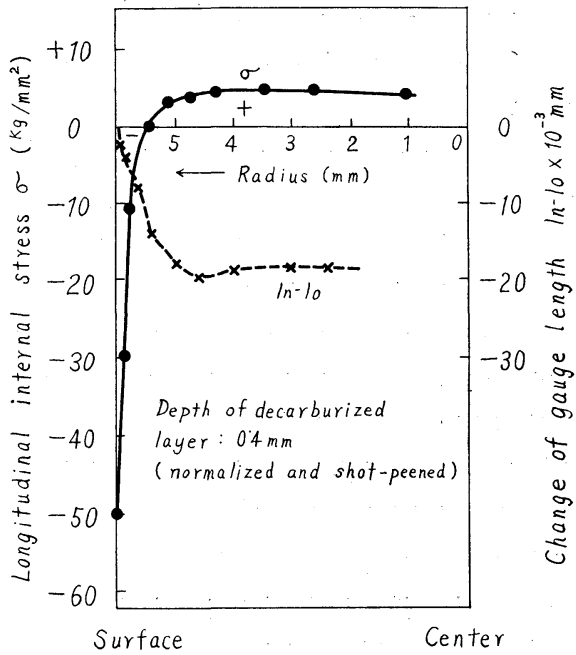

Fig. 12 The distribution of longitudinal internal stress in the cross section of decarburized carbon steel bar and the change of length caused by dissolution

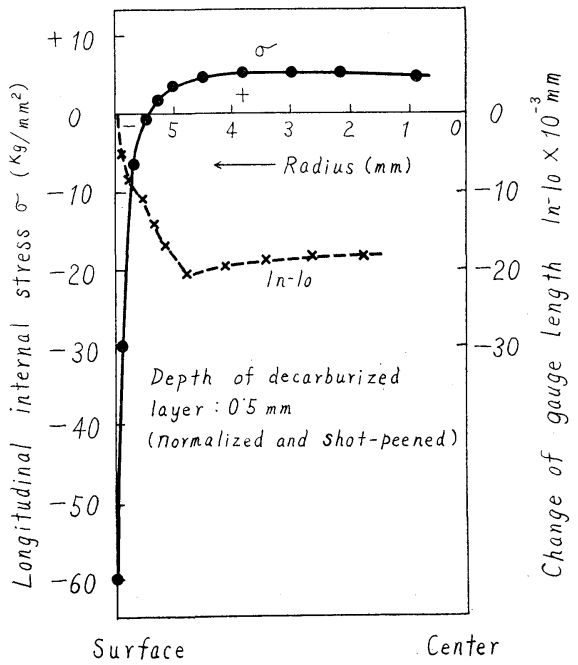

Fig. 13 The distribution of longitudinal internal stress in the cross section of decarburized carbon steel bar and the change of length caused by dissolution 
との差により，炭素含有量に勾配が生じて組織が異な り, 比重は表面におけるフェライトの $7 \cdot 86$ から内部 の $0.61 \% \mathrm{C}$ 鋼の 7.83 へとしだいに減少して，ここに 内部応力が生ずる。すなわち, 試片の表面部は脱炭に より収縮しようとするけれども，横断面における脱炭 部の面積は, 内部の脱炭していない部分の面積に比へ ていちじるしく僅小であるため, 表面層は引張られる ことになって,ここに引張の内部応力が発生する。内 部は表面層の収縮しようとする作用により圧縮応力を 受け，これらあい反する二つの応力によるひずみ力の 大きさが等しくなって平衡状態にあると考えられる。

Fig. 14 は, 表面に打的る最大内部応力と脱炭層の 深さとの関係を図示したもので，脱炭焼準および脱炭 焼入れ，焼戻しの調質処理したものは実線曲線で，脱 炭焼準後ショットピーニングしたものは点線曲線で示 している.

この図にみられるように，焼準鋼では脱炭深さが深 くなるにつれて最大引張内部応力の值はしだいに減少 し, 脱炭深さの深いものは浅いものに比べていちじる しく減少している。この減少は脱炭深さが增せば脱炭 部の面積が増加し，収縮しようとして内部に及ぼす圧 縮力が増し，そのため内部の収縮変形は増大寸るため 外側の受ける引張応力は小さくなり, 内部の压縮応力 の值は大きくなってくる。

\section{（II）焼入れ，焼戻し調質処理した場合}

脱炭後調質した試験片における内部応力の分布状況 は，上揭の脱炭焼準の試験片と同様であるが，最大内 部応力の值は Fig. 14 に示すように脱炭深さが深くな るに従い表面における最大引張内部応力は小さくなっ ていることは，焼準組織のものと同様であるがその值

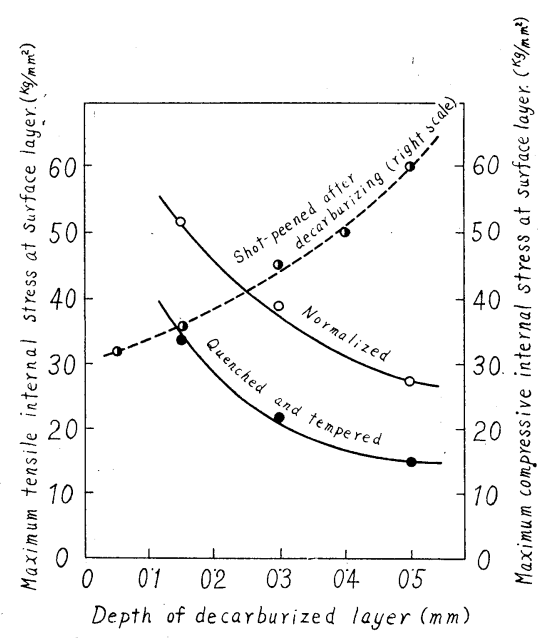

Fig. 14 Relationship between the surface maximum internal stress and the depth of decarburized layer
はいずれも小さい.

一般に鋼は焼入れ，焼戻し処理を受けると熱応力と 変態応力とが発生し, 試験片の内部と外部に収縮, あ るいは膨張の不均一ひずみが生ずる。すなわち, 焼入 れのための急冷により試験片の表面温度は急激に低下 するが，内部一ゆくにつれて冷却は遅れ，この冷却速 度の遅速による収縮状況の不同により熱応力が発生し， また，表面部は内部より早のマルテンサイト化して膨 張し，ここに変態応力が発生する。これら二つの応力 が同時におこり, 表面部に压縮, 内部に引張の内部応 カが発生することは多く研究されている。焼入れによ りマルテンサイト組織となって膨張したものを焼戻し すれば,ソルバイト組織となって収縮するため, 焼入 れにより生じた内部応力は小さくなる。このように脱 炭していない焼入れ，焼戻し鋼における内部応力の分 布は脱炭試験片を焼入れ，焼戻し処理したときの内部 応力の分布とちょうど正反対となっている。これは前 節で述べたように，脱炭によって表面部の組織はつェ ライトに近くなって収縮し，かっ，焼入れによってマ ルテンサイト变態はおこらないのに対し，中心部では マルテンサイト変態が抗こって膨張するため, 引張ら れる結果となって引張の内部応力が発生し, これを焼 㞍しするときは中心部のマルテンサイト組織が，ソル バイト組織となって中心部は収縮して表面の内部応力 が減少するのは当然である。

\section{(III）ショットピーニングを施した場合}

表面に引張内部応力, 中心部に圧縮内部応力が存在 している脱炭鋼棒の表面に, ショットピーニングを施 したときの内部応力の分布状態は, ショットピーニン グ前の脱炭のままの試片における分布とは正反対とな り, 表面の脱炭部には圧縮内部応力, 中心部には引張 内部応力が存在し，Fig. 14 の点線曲線で示すように， 表面における最大圧縮内部応力は, 脱炭深さが増すに 従って増大している．このように, 表面の脱炭層にシ ョットピーニングを施せば，ショットの衝突により打 ちたたかれて表面層だけ塑性変形をおこして伸ばされ るために, 圧縮内部応力の発生する結果となる。この 最大値は脱炭深さの増加とともに上畀している。

ショットピーニングは, 脱炭深さのいかんにかかわ

Table 3 Maximum internal stress at surface

\begin{tabular}{c|c|c|c}
\hline $\begin{array}{c}\text { Depth of } \\
\text { decarburized } \\
\text { layer }(\mathrm{mm})\end{array}$ & $\begin{array}{c}\text { Decarburized } \\
\text { only } \\
\left(\mathrm{kg} / \mathrm{mm}^{2}\right)\end{array}$ & $\begin{array}{c}\text { Decarburized } \\
+ \text { shot-peened } \\
\sigma_{1}+\sigma_{2} \\
\left(\mathrm{~kg} / \mathrm{mm}^{2}\right)\end{array}$ & $\begin{array}{c}\text { Shot-peened } \\
\text { only } \\
\sigma_{2}\left(\mathrm{~kg} / \mathrm{mm}^{2}\right)\end{array}$ \\
\hline 0.15 & +52 & -35 & -89 \\
0.3 & +40 & -45 & -85 \\
0.4 & +33 & -50 & -83 \\
0.5 & +25 & -60 & -85 \\
\hline
\end{tabular}


らず，同一条件で施したものであるから，いま脱炭の みによって生ずる表面最大内部応力を $\sigma_{1}$, ショットピ 一ニングのみによって生ずる表面最大内部応力を $\sigma_{2}$ とすれば，脱炭後ショットピーニングしたものの表面 最大内部応力は， $\sigma_{1}$ と $\sigma_{2}$ との和で与えられる。した がってこれからショットピーニングのみによって生 ずる内部応力 $\sigma_{2}$ を求めると Table 3 の結果となり, 脱炭深さにかかわらず約 $85 \mathrm{~kg} / \mathrm{mm}^{2}$ の圧縮内部応力 の生ずることが知られる。

\section{6. 総括}

表面脱炭した機械構造用炭素鋼材の疲労破壊を論ず るさい，実用的見地から大きな影響を与えると考えら れる表面脱炭による内部応力の分布状態を, 直径 12 $\mathrm{mm}$ なる $0.61 \% \mathrm{C}$ 炭素鋼棒の脱炭層をもつ焼準組織 のもの，ならびにこれを焼入れ，焼戻し調質したもの， および脱炭焼準したものにショットピーニングを施し たものについて求めた。この場合の内部応力の測定は， $10 \%$ 硝酸溶液中で表面より漸次溶解し, そのときの直 径および長さの変化を求め，これより縦軸方向の内部 応力を算出する方法によった。その結果を総括すると，

（1）表面脱炭した焼準鋼棒の横断面においては, 表面に縦軸方向の最大引張内部忍力, 中心部には圧縮 内部応力が分布している。

（2）脱炭深さが増すにつれて最大引張内部応力は 減少する.脱炭深さ $0.15 \mathrm{~mm}$ では約 $52 \mathrm{~kg} / \mathrm{mm}^{2}$ の 最大引張内部応力が存在し, 深さが $0.5 \mathrm{~mm}$ になれば 約 $27 \mathrm{~kg} / \mathrm{mm}^{2}$ となって半減している. 中心部におけ る圧縮の最大内部応力は $3 \sim 6 \mathrm{~kg} / \mathrm{mm}^{2}$ 程度である.

（3）脱炭した鋼に焼入れ，焼戻しの熱処理を施せ ば内部応力の分布状態は焼準の場合と同じであるけれ ぞも, 表面に存在している最大引張内部応力の值はい ちじるしく減少する。

脱炭深さ $0.15 \mathrm{~mm}$ では $35 \mathrm{~kg} / \mathrm{mm}^{2}$ ，脱炭深さが $0.5 \mathrm{~mm}$ となれば $15 \mathrm{~kg} / \mathrm{mm}^{2}$ となって脱炭深さが増 すにつれて減少している。
（4）脱炭鋼に存在する内部応力の分布はショット ピーニングを施すことにより正反対となり，表面層に 圧縮内部応力, 内部に引張内部応力が存在する.

脱炭層が深くなるにつれて表面の最大圧縮内部応力 は増加し, 脱炭深さ $0.05 \mathrm{~mm}$ で $32 \mathrm{~kg} / \mathrm{mm}^{2}$, 深さ $0 \cdot 5 . \mathrm{mm}$ では $60 \mathrm{~kg} / \mathrm{mm}^{2}$ に及んでいる。

（5）第 1 報で脱炭によって疲労耐久限の減少する ことを述べたぶ，その理由として表面層に存在する最 大引張内部応力が大いに影響するものと考えられる. すなわち，脱炭鋼棒の表面に作用してるい最大引張内 部応力に繰返曲げ荷重による最大引張応力が加わると， 表面における実働引張応力はいちじるしく大となり, これがフェライト部の真の破断力をこえて，微小き裂 が無脱炭鋼に比べて早く発生するからである.

また，のちに報告するように，脱炭鋼にショットピ 一ニングを施せば疲労限は上昇するが，その理由の一 つは表面部に圧縮内部応力が存在して実働応力が小さ くなるためと考えられる。

終りにのぞみ, 試験片にショットピーニング加工し ていただいた神奈川県工業試験所技師大野明氏に厚く 感謝の意を表する。

\section{参 考 文 献}

1)上时太郎, 上田祐男, 材料試験, 8, 65, 170 (昭34)

2) G. Sachs, Zeits. Metallkunde, 19, 352 (1927) Metall wirtsch., 10, 783 (1931)

3) E. Heyn and O. Bauer,

Inst. z. Metallsgr, 1, 16 (1911)

Stahl u. Eisen, 32, 2097 (1912)

4) Taro Ueda, Science Reports, Tohoku Imp. Univ., Series 1, 26, 434 (1939)

Tech. Roports, Osaka Univ., 3，21 (昭28)

5）朴多，橋本，Tohoku Sci. Rep., 10， 75 (1921)

6) 水多, 松下, Tohoku Sci. Rep., 8, 89 (1919)

7) 松下, Tohoku Sci. Rep., 9, 247 (1920)

8）上田太郎，久米北茂，日本金属学会誌， $17,12,623$ (昭28)

9) H. Bühler, H. Buchholtz u. E.H. Schulz, Arch. Eisenhüttenwes., 5, 413 (1931)

10) H. Bühler, H. Buchholtz, Arch. Eisenhüttenwes., 6, $247(1932)$ 